\title{
"The Rising: Ireland: Easter 1916," Fearghal McGarry (New York: Oxford University Press, 2010) and "Guerrilla Warfare in the Irish War of Independence, 1919-1921," Joseph McKenna (Jefferson, NC and London: McFarland \& Company, Inc., Publishers, 2011)
}

Edward J. Hagerty American Public University

Follow this and additional works at: https://digitalcommons.usf.edu/jss

Part of the Defense and Security Studies Commons, National Security Law Commons, and the Portfolio and Security Analysis Commons

pp. 61-67

\section{Recommended Citation}

Hagerty, Edward J.. "'The Rising: Ireland: Easter 1916," Fearghal McGarry (New York: Oxford University Press, 2010) and "Guerrilla Warfare in the Irish War of Independence, 1919-1921," Joseph McKenna (Jefferson, NC and London: McFarland \& Company, Inc., Publishers, 2011)." Journal of Strategic Security 4, no. 3 (2011) : 61-67.

DOI:

http://dx.doi.org/10.5038/1944-0472.4.3.5

Available at: https://digitalcommons.usf.edu/jss/vol4/iss3/6

This Book Review is brought to you for free and open access by the Open Access Journals at Digital Commons @ University of South Florida. It has been accepted for inclusion in Journal of Strategic Security by an authorized editor of Digital Commons @ University of South Florida. For more information, please contact digitalcommons@usf.edu. 
"The Rising: Ireland: Easter 1916," Fearghal McGarry (New York: Oxford University Press, 2010) and "Guerrilla Warfare in the Irish War of Independence, 1919-1921," Joseph McKenna (Jefferson, NC and London: McFarland \& Company, Inc., Publishers, 2011) 


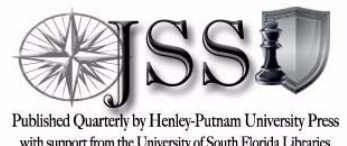

Published Quarterty by Henley-Putnam University Press

\section{Book Reviews}

The Rising: Ireland: Easter 1916. By Fearghal McGarry. New York: Oxford University Press, 2010. ISBN: 978-0-19-280186-9. Notes. Bibliography. Index. Photographs. Maps. Pp. xiv, 365. $\$ 29.95$.

Guerrilla Warfare in the Irish War of Independence, 19191921. By Joseph McKenna. Jefferson, NC and London: McFarland \& Company, Inc., Publishers, 2011. ISBN: 978-o7864-5947-6. Ebook ISBN: 978-0-7864-8519-2. Appendices. Notes. Bibliography. Index. Photographs. Maps. Pp. x, 290. $\$ 65.00$.

These complementary works are among two of the most recent efforts to make use of the nearly 1,800 interviews conducted by the Irish government's Bureau of Military History starting in 1947, but not made available to historians until 2003. The witness statements collected by the Bureau comprise 36,000 pages of evidence and more than 150,000 documents chronicling the personal experiences of Irish citizens and soldiers during the events of the early 2oth century through the War of Independence. Together, these books provide a chronological story of the Easter Rising and the War of Independence.

Unfortunately, no subsequent volume is likely to conclude what would be an obvious trilogy with the completion of a new study of the Irish Civil War based on the Bureau's collection. Interviewers seldom questioned witnesses about their role in that sad affair, the wounds of which festered among families and neighbors for many years afterwards, and which remains to this day an unfit subject for discussion among many in Ireland. Despite the Bureau's short-sighted decision to ignore the Civil War in its interviews, historians must be grateful for the work that was done to preserve accounts of the Rising and the War of Independence.

Though very different books, these works provide an interesting and useful glimpse into how those interviews can enhance our understanding of the events. Lessons applicable to students and professionals in the fields 
Journal of Strategic Security, Vol. 4, No. 3

Journal of Strategic Security

of Intelligence and Counterterrorism are apparent throughout both books; and like many subsequent leaders of wars of national liberation, students and professionals would do well likewise to note the universality of goals, strategies, and tactics. Weaponry, it seems, is mostly what differentiates the efforts of Irish men and women to win their freedom from the efforts of Ho Chi Minh to unite his country. Parallels with today's insurgencies should also not be lost on us.

Fearghal McGarry's book is the stronger of the two. A Senior Lecturer in History at Queen's University, Belfast, McGarry provides a tale of the Easter Rising of 1916 that is effectively organized, highly insightful, and exceedingly well-written. McGarry does not attempt a full historical account of the Rising, and for that purpose one would do well to consult Charles Townshend's Easter 1916: The Irish Rebellion, published by Penguin in 2005. Instead, his stated purpose is to "convey how the rebellion was experienced, particularly by ordinary Volunteers and civilians...." (p. 124). He is too modest. He does much more than that, starting with a lucid account of the events that shaped the generation of Irishmen destined to live during the seminal period that marked a watershed in the course of Irish history. He first recognizes the pitfalls of using the Bureau's interviews as sources, noting how certain memories create "retrospectively...a sense of meaning in the narrative of one's own life..." and cloud the "multitude of influences" (p. 39) that shaped individual politicization. For many ordinary citizens, McGarry claims, that politicization encompassed a hostility to Britain, the embrace of a distinctive Irish culture, and "a commitment to an abstract ideal of Irish freedom" (p. 41).

McGarry next chronicles the rise of a fighting force capable of sustaining a war of national liberation, starting with the response to the Ulster Unionist formation of the Ulster Volunteer Force (UVF). It now seems odd in retrospect, but some republicans of the day celebrated the formation of the UVF as at least some measure of resistance to British authority. Many did not take it seriously, failing to recognize it as a real step towards the radicalization of Unionism. Still, the counter to that force was the formation of the Irish Volunteers, quickly infiltrated at top leadership levels by the more militant Irish Republican Brotherhood (IRB). Founders of the Volunteers saw their organization as a bulwark against the threat posed by the UVF, while IRB leaders among the Volunteers viewed their army as the foundation for insurrection.

McGarry uses this opportunity to bring in the Bureau's interviews to describe the social structure of the Volunteers. The absence of "people of importance" (p. 60) among the top leaders led some authorities to under-

62 
estimate the threat posed by the Irish Volunteers. Though the average Volunteer was of modest social standing, the same was not so true for the women of Cumann na mBan, an auxiliary group formed to support the all-male Volunteers. McGarry provides less insight into the much smaller Irish Citizen Army (ICA), a socialist labor force then led by James Connolly. In socialist fashion, women were welcomed among its ranks as fighters, providing opportunities for zealous radicals like Countess Constance Markievicz to don a fashionable ICA uniform and wield an oversized revolver.

No matter their social status or their aims, those who took up arms against British rule in 1916 were deeply motivated, but by what? McGarry tackles that question by relying again on the accounts of participants. Historians have often responded to that question by citing the embrace of Patrick Pearse's ideas of a blood-sacrifice redeeming the Irish nation; such ideas have an appeal, considering the deeply religious nature of Irish society at that time. The futility of such an ill-armed, badly trained, and strategically inept force standing up to the might of the British Empire would seem to support the notion that the Rising was little more than mass suicide. Yet, McGarry points out, at the time the rebellion was planned, Pearse was too minor a character among the Volunteers to have had such influence on the decision to act. It seems more likely that ideas revolving around German assistance that might lead to success were seriously considered. Or, in the event of the rebels' defeat and a German victory on the Continent, the claim to a seat at the table when a peace conference ended The Great War was possible. But even those reasons are less likely than two simple facts. The necessity for an insurrection during the First World War, while Britain was taxed on the Western Front, was a "rational...moral and historical imperative if Fenianism was to retain any credibility or future" (p. 98). In addition, there was an emotional component as well, "born out of frustration, shame, and pessimism" (p. 98).

McGarry also poses the question of how the authorities failed to predict the onset of the Rising. The finger must be glaringly pointed at the British Intelligence system. It comprised no less than five separate intelligencegathering bodies, most of which failed to share information with one another, but strangely too, failed to share it even with those in Dublin Castle who might have acted on it. In a comment that could reflect any number of more recent intelligence failures, McGarry notes that in addition to the convoluted bureaucracy, the failure stemmed more from an inability to act on the information possessed, rather than from a lack of information itself. The Irish police forces also come in for criticism in that they failed to devote proper resources to intelligence-gathering. Again echoing modern parallels, one sees that the speed at which intelligence 
information is gathered, analyzed, disseminated, and acted upon is key to success. Only one human source provided advance warning of the Rising, and that information was still navigating the police bureaucracy two days later when the event came to pass. Ultimately, though, McGarry places blame on the political leaders in Dublin Castle who had it within their power to reform the intelligence processes then in use.

Despite all the discussion about motivation and rationale for the Rising, the fact remains that all those factors applied only to those who actually came out during Easter Week-only a small percentage of the number of Volunteers on the rolls. Only about a thousand Volunteers mobilized initially, with another three hundred or so falling in over the next few days. Although there was initial disagreement among some Volunteer leaders about the rectitude of their judgment, and miscommunication about whether or not to mobilize, once the event was underway, what kept so many Volunteers at home? No one has satisfactorily answered that question. On the other hand, what prompted one young soldier from the Royal Irish Rifles, home on leave in Dublin, to respond to a call to return to his barracks by reporting instead to his family home and joining his two Volunteer brothers? "'My mother put her arms around me,' he recalled, 'God bless you, I knew you would do it,' and she burned my British uniform" (p. 126).

Unified leadership and a more militant ethos led to about two-thirds of Connolly's ICA turning out. It was a much higher percentage than the Volunteers, but it amounted only to another 219 men and woman under arms. One is left to speculate kindly that most of the Volunteers viewed their chances of success more rationally and were not so zealous as to allow their enthusiasm to overwhelm their common sense. Yet, had it not been for those who made the sacrifice, it is highly questionable whether Mr. McKenna would have had anything to write about in the next book under review here. Fortunately for Ireland, a good showing of committed republicans turned out to see what they could do for Kate Houlihan in 1916.

Finally, it was the legacy of the Rising that set the stage for the next step in Ireland's freedom from British rule and its evolution as a nation. Without the Rising, McGarry states, "Irish nationalism would not have united under the banner of republicanism," previously considered by most to be an extreme and unattainable goal. The Rising also revived and legitimized "the physical force tradition" in Ireland. Finally, though not the subject of these books, the Rising undermined the possibility of compromise, thus leading directly to the onset of the Irish Civil War. Those committed to a republic could not settle on an Irish Free State. Meanwhile, in 1919, Irish 
men and women were again prepared to strike a blow for freedom, this time far more successfully.

Joseph McKenna, former senior assistant librarian in the Central Library at Birmingham, England, takes up that story and makes very different use of the Bureau of Military History statements, liberally interspersing material from more traditional accounts, such as the widely familiar memoirs of Tom Barry, Dan Breen, and Ernie O'Mally. McKenna also brings more of the British perspective into his work, using resources from the Public Records Office in London, as well as Parliamentary Papers. His book is of a different caliber than McGarry's in that McKenna allows the sources to speak largely for themselves with less context and historical analysis. It is less a book of ideas than a book of facts, though they are interesting ones and generally well presented. It is also replete with first-hand observations from participants in the events that followed the 1916 Rising, and that in itself is of much value to readers.

McKenna begins with a chapter that briefly summarizes the events of Easter Week, 1916. He then moves on to a discussion of political and military reorganization in two following chapters. Of the Rising, McKenna notes that the harsh treatment and executions of the Irish leaders set the tone for a vital change in public sentiment that would be necessary in an ensuing war of independence. British prison camps became "the universities of Republicanism" (p. 39), binding men to their cause and enabling the revitalization of an army in Ireland upon their release and return home. The Conscription Bill that passed in the spring of 1918, when the final result of the First World War was still very much undecided, was the issue that led most directly to widespread public opposition to British governance. The threat of conscription provided an immeasurable boost to the Irish Volunteers, poised to defend against that threat by force. In the end, force proved unnecessary, and the war ended without conscription being enacted in Ireland. Nevertheless, the Irish Volunteers (known subsequently as the Irish Republican Army (IRA)) continued to evolve into an effective force. Structural changes at the General Headquarters level led to a focus on propaganda with the creation of a department for that purpose. McKenna notes that the War of Independence was "perhaps the first modern war where propaganda...was to play a major part...in shaping opinion...." (p. 51).

Most importantly, before that evolving army could take up arms to dispute British rule in Ireland, the transition of public opinion from apathy to support was first required. That support built slowly, with resentment against the British, as noted above, resulting from their treatment of the leaders of 1916 and the threat of compelling Irishmen to 
fight the Germans. The anti-conscription campaign was the first major step in converting the populace to the practice of passive resistance. Irish labor unions added to that resistance with a series of general strikes. Eventually, the height of resistance was reached by "just ignoring the British system" (p. 71) when Republican courts began to administer justice throughout Ireland.

Once war began, many of the successes or failures hinged on the outcome of the intelligence war, which is also the title of another chapter in the book. McKenna, like McGarry, notes that British failures were attributable to the existence of multiple intelligence organizations with overlapping functions, "but little exchange of information" (p. 79). That failure of communication played a significant role in Irish successes, and the fact that the problem persisted even after the failures of 1916 is a lesson that should not be lost on modern intelligence professionals. Largely, though, the story of the intelligence war is an age-old tale, with successes on both sides owing mostly to the use of informants. With hundreds of Irish citizens in the employ of Dublin Castle, it stood to reason that some would supply information to the IRA, which ultimately got the best of the British as a result. Perhaps most importantly, it allowed the IRA to exercise some measure of control over the capital. The propaganda value of successful attacks in Dublin was significant. Attacks in the city undermined British authority and demonstrated to the world that Britain was not even "in control of the most heavily patrolled city in the world" (p. 97).

Discussion of the war years progresses through three chapters, each devoted separately to one year of the conflict, starting with the Soloheadbeg Ambush on January 21, 1919, and ending with the truce and eventual Anglo-Irish Treaty of December 6, 1921. These chapters follow the war's events from the first-hand accounts of the participants. Actions consisted primarily of raids on Royal Irish Constabulary (RCI) barracks to obtain arms, or ambushes of RIC or British Army troops at opportune positions along rural Irish roads. Earlier in the war, the need for arms and munitions dictated Volunteer efforts. Later, attacks on Crown forces intensified.

McKenna points out some failures that were largely attributable to a lack of experience and training. In one case, Volunteers captured an officer of the coastguard garrison at Castletownberre Station. They failed to search him, and at an appropriate moment the officer pulled a revolver and wounded several of his would-be captors. In another failed effort, Volunteers returned to an ambush site three days running in an effort to catch an expected motorized army patrol. Instead, their presence must have been revealed by some observer, and the ambushers soon found them- 
selves on the receiving end of a British ambush. Still, the nature of the war favored the Volunteers, who derived support from the local population and could melt away into the towns or countryside after a successful ambush.

As more and more Volunteers were identified or suspected of insurrection and unable to return to their homes, flying columns of such men were formed on the Boer War model. Instead of acting in an individual and uncoordinated fashion, these men formed a standing body of troops able to act much more decisively. The flying column, McKenna claims, is what evened the odds between the smaller number of Volunteers and the overwhelming numbers of Crown forces. The flying columns around the country eventually grew large enough to take on sizable contingents of British forces and prevail. Their knowledge of the country and an active intelligence capability typically enabled them to avoid even large-scale British attempts to surround and destroy them. The story is an eerily familiar one. One could undoubtedly substitute any number of names for "Irish" and "British" and tell much the same tale.

McKenna concludes with precisely that observation regarding the legacy of the Irish War of Independence, claiming that it served as the model for the eventual downfall of British Imperialism (though he fails to credit the impact of World War II as contributing to that trend). Accounts of the war were required reading at many military academies. In less formal settings, other revolutionaries of the 2oth century made a similar study of the subject. It served them well. The difficulties of countering wars of national liberation persist.

Both of these books are worth reading for the perspective they provide on all the myriad facets of revolutionary thoughts, ideologies, politics, and military actions that still ring true today. Perhaps no more telling indication of that is McKenna's quote from the Lord Mayor of Cork, Terrence MacSwiney, who observed in 1920 that "It is not those who can inflict the most, but those who can suffer the most who will conquer" (p. 132). Ho Chi Minh must have watched the events unfolding in Ireland with keen interest.

Edward J. Hagerty, Ph.D., American Public University 